\title{
REPORTS AIND PROOEEDINGS.
}

\section{Minera logical Society.}

June 19.-W. Barlow, F.R.S., President, in the Chair.

Dr. G. F. Herbert Sinith: On the Problem of Sartorite. The examination of crystals kindly supplied for the purpose by Dr. C. O. Trechmann and IIr. R. H. Solly showed that the faces fall into zones which are only partially congruent. Just as in the case of calaverite earlier investigated by the author, there appear to be simultaneously in certain of the crystals five distinct lattices. The rertical spacing and the relative positions of the vertical planes remain unchanged, but in passing from the central lattice to the two iviug on either side there is a distinct shear which varies in direction, though apparently not in amount, from crystal to crystal.

I)r. A. Scott: Note on a Curious Case of Devitrification. The glass of an old bottle found in river sand about four feet below the surface in Leren Shiprard, Dumbarton, has become almost completely crystallized. The crystals, which have a composition corresponding nearly to $2 \mathrm{CaO} . \mathrm{Na}_{2} \mathrm{O} .5 \mathrm{SiO}_{2}$, are accompanied by some dark-coloured microlites. A piece of a glass which by accident had been allowed to cool slowly showed the same crystals and microlites, and in addition a few small needles with high refraction and large birefringence.

Dr. G. T. Prior: 'The Meteorites of Simondium, Eagle Station, and Amana. The results of analyses showed that the Amana stone belonged to the cronstadt, with some approach to the baroti type; that Eagle Station is an exception to other pallasites in containing iron richer in nickel and olivine correspondingly richer in ferrous oxide; and that Simondium was closer to the grahamites than to the howardites, since like other grahamites it contained nickeliferous iron and olivine in chemical composition similar to those of the pallasites, but with pyroxene and atorthic felspar similar to those of the howardites and eucrites.

\section{CORFESEONDENOE.}

\section{FROM THE FRONT.}

Dear Dr. Woonward,-I have by no means forgotten your kind letters, but $I$ hare not been in a position to write to you of late. The business in the Artillery line has been far too brisk to allow me quiet to get any correspondence done. Fortunately for me, the other night I did not retire to rest at my usual time, for my "dug-out" fell in and buried my "kit" under 8 foot of earth, so I cannot grumble at my luck, even though I have been out here now nine months without any leave.

Strangely enough, the fall of my "dug-out" brought out a rather interesting little geological section: a pocket of chalk about a foot in greatest diameter, with streaks running out of it for about 2 feet in one direction only, was exposed in the sandy cliff, though the solid chalk below had still another 15 feet of sand separating it from this pocket. The other day also I came across the finest illustration of 
a. dried-up river-valley that $I$ have yet seen. The terraces were distinct, the last lerel of deposition of silt being very pronounced. The layer of chalk exposed was only 4 inches thick, being covered elsewhere by silt at the bed of the river and with clay higher up.

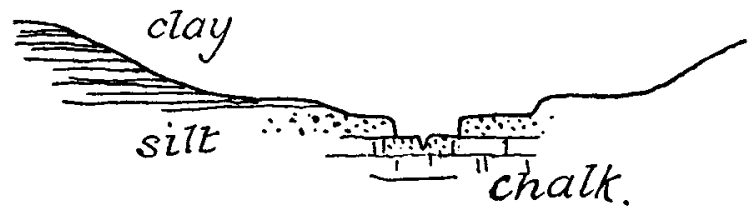

This is the way I amuse myself in odd moments when dodging Hun shells and encouraging destruction on the part of our own.

SIFGE BATTERY,

E. W. H.

SOMEWHERE IN FraNCE.

June 7, 1917 .

OBITUA.EY.

PROFESSOR WILLIAM BULLOCK CLARK,

A.B., Ph.D., LL.D., For. Corr. Geol. Soc. Lond.

Bokr December 15, $1860 . \quad$ Died Joly 27, 1917.

Professor Wilitam Bullock Clark, A.B., Ph.D., LL.D., head of the Department of Geology in the Johns Hopkins University and Director of the Marcland Geological Surrey from its organization in 1896, died suddenly on July 27, 1917.

Professor Clark was born in Vermont on December 15, 1860. In his earlier years he was an active student of in vertebrate palæontology, especially of the Echinoidea. In later years he attained his great influence largely as an organizer of research. He was a Foreign Correspondent of the Geological Society of London, a member of the National Academy of Sciences, Treasurer of the Geological Society of America, President of the Association of American State Geologists, and a member of many other learned societies both at home and abroad. At the time of his death he was actively engaged as chairman of the Committee on Highways and Natural Resources of the Maryland Council of Defence, and of two sub-committees of the National Council of Defence.

\section{MISOFIIANTOUS.}

Geologichl Chair in Liverfool University.-We are glad to learn that Dr. P. G. H. Boswell, F.G.S., Assoc. R.C.S., D.I.C., of the Imperial College of Science, South Kensington, London, S.W., has been selected as Professor to fill the recently founded Herdman Chair of Geology in the Liverpool University.

Earthqdake and 'lidal Wave, Samoa.-A dispatch received at Melbourne from Sura states that a severe earthquake and a tidal wave hare caused damage to the Samoa group of islands. An earthquake has been experienced in the Friendly Islands. 